\title{
The Temperature Dependence of the Properties of Electrolyte Solutions. III. Conductance of Various Salts at High Concentrations in Propylene Carbonate at Temperatures from $-45^{\circ} \mathrm{C}$ to $+25^{\circ} \mathrm{C}$
}

\author{
J. Barthel, H. J. Gores, and G. Schmeer \\ Chemisches Institut der Universität Regensburg
}

\section{Elektrochemie / Lösungen / Transporterscheinungen}

Specific conductances of $\mathrm{Et}_{4} \mathrm{NPF}_{6}, \mathrm{Pr}_{4} \mathrm{NPF}_{6}, \mathrm{Bu}_{4} \mathrm{NPF}_{6}, \mathrm{LiPF}_{6}, \mathrm{KPF}_{6}, \mathrm{LiClO}_{4}$, and $\mathrm{KSCN}$ in propylene carbonate were studied at high concentrations in the temperature range from $+25^{\circ} \mathrm{C}$ to $-45^{\circ} \mathrm{C}$. Data are fitted by a least-squares method to a four-parametric empirical equation, yielding the maximum specific conductance $\kappa_{\max }$ and the corresponding concentration $\mu$. Within the frame-work of a hydrodynamic model the Stokes-radii of the ions and the solvent viscosity are found to be the most important conductance-determining parameters, affecting both $\kappa_{\max }$ and $\mu$. Ionic association in solutions with propylene carbonate as the solvent is not of significant impertance. Kinetic treatment of conductance yields temperature-dependent activation energies, but at any one temperature equal for all salts at concentration $\mu$.

Die spezifische Leitfähigkeit konzentrierter Lösungen von $\mathrm{Et}_{4} \mathrm{NPF}_{6}, \mathrm{Pr}_{4} \mathrm{NPF}_{6}, \mathrm{Bu}_{4} \mathrm{NPF}_{6}, \mathrm{LiPF}_{6}, \mathrm{KPF}_{6}, \mathrm{LiClO}_{4}$ und $\mathrm{KSCN}$ in Propylencarbonat wurde im Temperaturbereich zwischen $+25^{\circ} \mathrm{C}$ und $-45^{\circ} \mathrm{C}$ untersucht. Die Datenanalyse mittels eines Ausgleichs nach einer vier-parametrigen empirischen Gleichung liefert für jede Temperatur die maximale spezifische Leitfähigkeit $\kappa_{\max }$ mit zugehörigem Konzentrationswert $\mu$. Die Stokes-Radien der Ionen und die Viskosität des Lösungsmittels erweisen sich für ein hydrodynamisches Modell als die wichtigsten leitfähigkeitsbestimmenden Parameter zur Diskussion von $\kappa_{\max }$ und $\mu$. Ionenassoziation spielt in Propylencarbonat als Lösungsmittel keine hervorragende Rolle. Die Behandlung des Transportprozesses im Rahmen eines kinetischen Modells führt zu temperaturabhängigen Aktivierungsenergien, die aber bei jeder Temperatur für alle Salze bei der Konzentration $\mu$ gleich sinc.

\section{Introduction}

The conductance of concentrated electrolyte solutions and its temperature dependence are of technological interest, e. g. high energy and low temperature batteries, electrolysis etc. However at present, only a few sets of comprehensive data which are suitable for the discussion of conductance-determining effects are available [cf. [1-3]]. Furthermore, a perusal of the literature shows remarkable deviations in the data.

For example, values of the specific conductance $\kappa$ of $1 \mathrm{M} \mathrm{LiClO}_{4}$ in propylene carbonate at $25^{\circ} \mathrm{C}$ in the literature are $5.6 \cdot 10^{-3}$
$\Omega^{-1} \mathrm{~cm}^{-1}[1], 4.356 \cdot 10^{-3} \Omega^{-1} \mathrm{~cm}^{-1}$ or $4.239 \cdot 10^{-3} \Omega^{-1} \mathrm{~cm}^{-1}$ [using the interpolation functions of [4]] and $3.9 \cdot 10^{-3} \Omega^{-1} \mathrm{~cm}^{-1}$ [from Fig. 4 in [5]].

Solutions of various electrolytes with PC (propylene carbonate) as the solvent were investigated over a temperature range $-45^{\circ} \mathrm{C}$ to $+25^{\circ} \mathrm{C}$ in steps of $10 \mathrm{~K}$ from dilute to saturated - or up to concentrations beyond the maximum specific conductance - in order to obtain comprehensive information for a first example of a non-aqueous system which is of technological interest, also. 


\section{Experimental}

\subsection{Materials}

Propylene carbonate (Fluka, purum $>99 \%$ ) was boiled for two hours in the presence of dried $\mathrm{CaO}$ to reduce its glycol content to about $20 \%$ of the initial value and was then distilled at reduced pressu:e ( $\sim 2$ Torr). Nitrogen was bubbled through the solvent at $60^{\circ} \mathrm{C}$ io remove the volatile impurities [6]. The final distillation was carried out in a specially designed column [3] (40 plates, packed with nichrome helices) at reduced pressure ( $<2$ Torr) and at a temperature of the still $<130^{\circ} \mathrm{C}$ to avoid decomposition of the product. Those middle fractions passing over between $(85.3 \pm 0.1)^{\circ} \mathrm{C}$ at $(1.8 \pm 0.3)$ Torr and $(88.7 \pm 0.1)^{\circ} \mathrm{C}$ at $(2.7 \pm 0.3)$ Torr were stored after purity control under nitrogen for further use. The distillation temperature agrees well with that known from Refs. $[6-8,26]$.

Purty control was achieved during the distillation process by continuously measuring the conductance. The stored product $\left(\kappa=2 \cdot 10^{-8} \Omega^{-1} \mathrm{~cm}^{-1}\right.$ ) contained $30-50 \mathrm{ppm}$ of glycol along with further unidentified traces $<1 \mathrm{ppm}$ of impurities detectable by gas chromatographic analysis [6] using a Porapak $Q$ column with $\mathrm{N}_{2}$ carrier gas and flame ionisation detector. In agreement with Fujinaga and Izutsu's observation [9] no UV-absorption was observed between 240 and $340 \mathrm{~nm}$, a steep increase beginning at $200 \mathrm{~nm}$.

$\mathrm{LiClO}_{4}\left(\mathrm{~K} \& \mathrm{~K}, \geq 99.8 \%\right.$ ), $\mathrm{KPF}_{6}$ (Schuchhardt, $98-100 \%$ ), and KSCN (Merck, p. a. $\geq 99 \%$ ) were fractionally recrystallised three times :rom highly purified water $\left(\kappa \leq 3 \cdot 10^{-7} \Omega^{-1} \mathrm{~cm}^{-1}\right)$, predried for $12 \mathrm{~h}$ in vacuum $(<1 \mathrm{Torr})$ at $50^{\circ} \mathrm{C}$ to $60^{\circ} \mathrm{C}$ and completely desiccated in a heated desiccator in vacuum at $200^{\circ} \mathrm{C}\left(\mathrm{LiClO}_{4}\right)$, $150^{\circ} \mathrm{C}\left(\mathrm{KPF}_{6}\right)$, and $50^{\circ} \mathrm{C}(\mathrm{KSCN}) . \mathrm{LiPF}_{6}(\mathrm{~K} \& \mathrm{~K}, 95-99 \%)$ was dried $n$ the same way but without the preceding recrystallisation. $\mathrm{Bu}_{4} \mathrm{NPF}_{6}(\mathrm{~K} \& \mathrm{~K},>97 \%)$ and $\mathrm{Pr}_{4} \mathrm{NPF}_{6}(\mathrm{~K} \& \mathrm{~K},>97 \%)$ were repeatedly recrystallized from methanol-water mixtures, $\mathrm{Et}_{4} \mathrm{NPF}_{6}$ ( $\mathrm{K} \& \mathrm{~K},>97 \%$ ) from acetone-ether mixtures, and dried in vacuum at $70 \mathrm{C}\left(\mathrm{Et}_{4} \mathrm{NPF}_{6}\right.$ and $\left.\mathrm{Pr}_{4} \mathrm{NPF}_{6}\right)$ or $50^{\circ} \mathrm{C}\left(\mathrm{Bu}_{4} \mathrm{NPF}_{6}\right)$ before storage under vacuum in the presence of sicapent (Merck).

Nitrogen as the protective gas and water for recrystallisation were prepared in the usual way.

\subsection{Conductance Measurements}

Corductance measurements were made with a set of capillary cells o: different cell constants, Fig. 1, immersed in a precise thermostat which could be set exactly to every temperature of the temperature programme $\left(+25^{\circ},+15^{\circ},+5^{\circ},-5^{\circ},-15^{\circ},-25^{\circ},-35^{\circ}\right.$, and $-45^{\circ} \mathrm{C}$ ) within $20 \mathrm{~min}$. The reproducibility of temperature and siort and long time deviations were $<10^{-3} \mathrm{~K}$. For details of the thermostat (see [34]).

The capillary cells, Fig. 1, yield high cell constants as these are required for concentrated solutions. They are provided with bulbs B1 ard B2 effecting a replacement of the solution between the electrodes E1 and E2 at every temperature step. To avoid bubbles the cells were filled through inlet $C$ from an appropriate filling device. All operations on the cell and the solutions were made under protective gas. An assembly lid, A, equiped with three conductance cells permits immersion of the cell arrangement into the bath ind hermetical sealing.

The calibration of the cells was based on the Jones-Bradshaw standerds, $0.1 \mathrm{D}$ and $1.0 \mathrm{D}$ aqueous potassium chloride solutions [10], at $25^{\circ} \mathrm{C}$. These values were used at all temperatures of the programme yielding an increasing systematic error with decreasing temperature which is a maximum $(+0.025 \%)$ at $-45^{\circ} \mathrm{C}$. For the temperature-dependence of the cell constants of capillary cells see $[25]$.

The conductance cells are connected in one arm of an a.c. bridge built according to present standard of technology guaranteeing a precis:on of $0.01 \%$ [ $\mathrm{cf}$ [ [34]]. Resistances of the solutions were deternined at various frequencies, $60<\frac{f}{\mathrm{~Hz}}<5,000$ and extra-

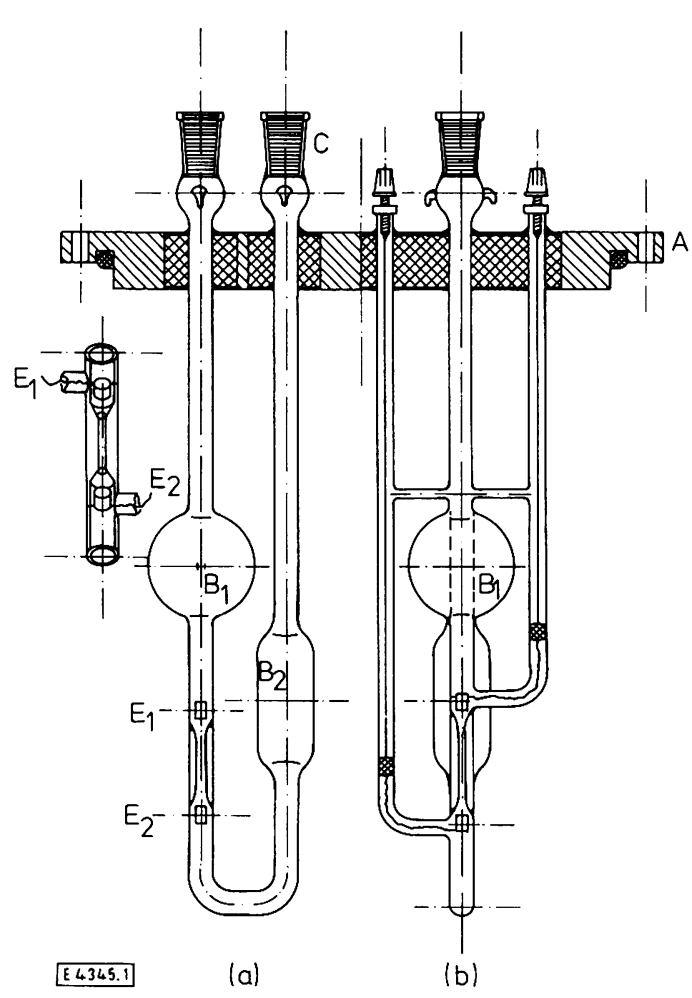

Fig. 1

Capillary cells $(\mathrm{a}, \mathrm{b})$ with assembly lid $(\mathrm{A})$ for immersion in the temperature bath. $E_{1}, E_{2}$ Electrodes, $C$ Inlet, $B_{1}, B_{2}$ Bulbs

polated to $f^{-1} \rightarrow 0$ in the usual manner. Taking into account the sources of error (calibration, remaining impurities of the salts, measurements) the specific conductances in Table 1 are certain within $0.1 \%$ with the exception of $\mathrm{LiPF}_{6}$ for which impurities may cause higher uncertainty [cf. [1]]. Measurements were carried out according to a method of isologuous sections in a temperature cycle $[3,34]$ beginning and ending at $25^{\circ} \mathrm{C}$.

\section{Analysis of Data}

Analysis of conductance data of concentrated solutions can actually best be achieved by means of empirical functions. Theoretically based equations like those known for dilute solutions are not so far available. Our experience with different empirical functions has proved that an equation published by Casteel and Amis [11]

$\frac{\kappa}{\kappa_{\max }}=\left(\frac{m}{\mu}\right)^{a} \exp \left[b(m-\mu)^{2}-a \mu^{-1}(m-\mu)\right]$

fits well specific conductances $k\left[\Omega^{-1} \mathrm{~cm}^{-1}\right]$ of all our solutions as a function of molal concentration $m[\mathrm{~mol} / \mathrm{kg}$ of solvent $]$ in a wide concentration range around the point of maximum specific conductance $\kappa_{\max }$ attained at concentration $\mu[\mathrm{mol} / \mathrm{kg}$ solvent $]$ Equation (1) fulfills the condition $\kappa=\kappa_{\max }$ if $m=\mu$.

The four quantities $\kappa_{\max }, \mu, a$, and $b$ are adjusted by a leastsquares method, all measuring values contributing with equal weight (in contrast to [11]). Our programme, analoguous to that of DeTar [12], uses the inversion of the coefficient matrix according to Househoulder $[13,14]$ avoiding deterioration of the matrix condition. Condition numbers of $10^{8}-10^{11}$ obtained from our data were distinctly below the critical limit of $10^{20}$ proving that our data analysis yields reliable coefficients in spite of a low degree of freedom. Standard deviations of the single values were observed with an order of magnitude of $10^{-6}<\sigma<10^{-5}$. Convergence was usually found after 4 to 5 iteration steps with a relative accuracy of $10^{-4}$ for the sum of the squared residuals. 
Table 1

Specific conductances $10^{3} \mathrm{\kappa} / \Omega^{-1} \mathrm{~cm}^{-1}$ of various electrolytes in propylene carbonate at molal concentrations $\mathrm{m} / \mathrm{mol} \mathrm{kg}^{-1}$ and temperatures $\theta /{ }^{\circ} \mathrm{C}$

\begin{tabular}{|c|c|c|c|c|c|c|c|c|c|c|}
\hline Electrolytes & $\frac{\mathrm{m}}{\mathrm{mol} / \mathrm{kg}}$ & $\frac{\theta}{{ }^{\circ} \mathrm{C}}$ & 25 & 15 & 5 & -5 & -15 & -25 & -35 & -45 \\
\hline \multirow[t]{6}{*}{$\mathrm{LiClO}_{4}$} & 0.27053 & & 4.1281 & 3.3481 & 2.6234 & 1.9660 & 1.3868 & 0.9100 & 0.5337 & 0.2678 \\
\hline & 0.52147 & & 5.3048 & 4.2296 & 3.2435 & 2.3614 & 1.6057 & 0.9972 & 0.5440 & 0.2460 \\
\hline & 0.68370 & & 5.4056 & 4.2506 & 3.2017 & 2.2797 & 1.5046 & 0.8976 & 0.4631 & 0.1937 \\
\hline & 0.78291 & & 5.3365 & 4.1604 & 3.0998 & 2.1735 & 1.4073 & 0.8178 & 0.4075 & 0.1628 \\
\hline & 1.05740 & & 4.8082 & 3.6428 & 2.6188 & 1.7540 & 1.0701 & 0.5733 & 0.2553 & 0.0873 \\
\hline & 1.26390 & & 4.1937 & 3.0987 & 2.1570 & 1.3865 & 0.8008 & 0.3990 & 0.1612 & 0.0485 \\
\hline \multirow[t]{5}{*}{$\operatorname{LiPF}_{6}$} & 0.116 & & 1.5937 & 1.2959 & 1.0209 & 0.7721 & 0.5542 & 0.3712 & 0.2253 & 0.1180 \\
\hline & 0.213 & & 2.7486 & 2.2202 & 1.7376 & 1.3024 & 0.9238 & 0.6090 & 0.3622 & 0.1858 \\
\hline & 0.412 & & 4.3079 & 3.4366 & 2.6452 & 1.9431 & 1.3419 & 0.8545 & 0.4847 & 0.2334 \\
\hline & 0.607 & & 5.1259 & 4.0346 & 3.0515 & 2.1914 & 1.4717 & 0.9019 & 0.4867 & 0.2186 \\
\hline & 0.891 & & 5.4030 & 4.1538 & 3.0511 & 2.1128 & 1.3502 & 0.7778 & 0.3856 & 0.1545 \\
\hline \multirow[t]{6}{*}{$\mathrm{KSCN}$} & 0.21089 & & 3.9975 & 3.2460 & 2.5513 & 1.9233 & 1.3743 & 0.9154 & 0.5512 & 0.2884 \\
\hline & 0.44662 & & 5.7936 & 4.6420 & 3.5868 & 2.6489 & 1.8426 & 1.1856 & 0.6810 & 0.3344 \\
\hline & 0.72132 & & 6.6929 & 5.2775 & 3.9989 & 2.8799 & 1.9370 & 1.1963 & 0.6489 & 0.2941 \\
\hline & 0.83051 & & 6.8618 & 5.3742 & 4.0406 & 2.8789 & 1.9134 & 1.1577 & 0.6136 & 0.2689 \\
\hline & 1.15538 & & 7.0060 & 5.3772 & 3.9352 & 2.7118 & 1.7245 & 0.9841 & 0.4816 & 0.1893 \\
\hline & 1.41113 & & 6.8838 & 5.1949 & 3.7242 & 2.4989 & 1.5339 & 0.8345 & 0.3822 & 0.1365 \\
\hline \multirow[t]{6}{*}{$\mathrm{KPF}_{6}$} & 0.11244 & & 2.5793 & 2.1068 & 1.6685 & 1.2666 & 0.9129 & 0.6131 & 0.3735 & 0.1975 \\
\hline & 0.20405 & & 3.9259 & 3.2001 & 2.5521 & 1.9057 & 1.3615 & 0.9047 & 0.5423 & 0.2804 \\
\hline & 0.38994 & & 5.7589 & 4.6520 & 3.6280 & 2.7016 & 1.8933 & 1.2241 & 0.7063 & 0.3458 \\
\hline & 0.57658 & & 6.7103 & 5.3671 & 4.1319 & 3.0232 & 2.0718 & 1.2980 & 0.7184 & 0.3312 \\
\hline & 0.76427 & & 7.1687 & 5.6673 & 4.2944 & 3.0891 & 2.0663 & 1.2453 & 0.6639 & 0.2884 \\
\hline & 0.98268 & & 7.3084 & 5.6853 & 4.2197 & 2.9607 & 1.9206 & 1.1173 & 0.5584 & 0.2226 \\
\hline \multirow[t]{6}{*}{$\mathrm{Et}_{4} \mathrm{NPF}_{6}$} & 0.26011 & & 5.542 & 4.513 & 3.558 & 2.693 & 1.933 & 1.291 & 0.7810 & 0.4099 \\
\hline & 0.36464 & & 6.964 & 5.652 & 4.439 & 3.343 & 2.383 & 1.578 & 0.9442 & 0.4876 \\
\hline & 0.49597 & & 8.384 & 6.776 & 5.294 & 3.961 & 2.792 & 1.835 & 1.080 & 0.5478 \\
\hline & 0.67278 & & 9.771 & 7.851 & 6.090 & 4.514 & 3.156 & 2.037 & 1.176 & 0.5776 \\
\hline & 0.88208 & & 10.870 & 8.673 & 6.671 & 4.893 & 3.373 & 2.138 & 1.208 & 0.5766 \\
\hline & 1.20960 & & 11.804 & 9.316 & 7.070 & 5.098 & 3.441 & 2.119 & & \\
\hline \multirow[t]{6}{*}{$\mathrm{Pr}_{4} \mathrm{NPF}_{6}$} & 0.1450 & & 3.1653 & 2.5720 & 2.0235 & 1.5278 & 1.0943 & 0.7303 & 0.4412 & 0.2321 \\
\hline & 0.2607 & & 4.7943 & 3.8726 & 3.0257 & 2.2645 & 1.6039 & 1.0552 & 0.6262 & 0.3207 \\
\hline & 0.4517 & & 6.5985 & 5.2721 & 4.0640 & 2.9970 & 2.0801 & 1.3331 & 0.7645 & 0.3736 \\
\hline & 0.4806 & & 6.8342 & 5.4525 & 4.1974 & 3.0867 & 2.1359 & 1.3632 & 0.7775 & 0.3775 \\
\hline & 0.7184 & & 7.8895 & 6.2134 & 4.7057 & 3.3885 & 2.2842 & 1.4101 & 0.7691 & 0.3516 \\
\hline & 0.9223 & & 8.3327 & 6.4888 & 4.8462 & 3.4320 & & & & \\
\hline \multirow[t]{6}{*}{$\mathrm{Bu}_{4} \mathrm{NPF}_{6}$} & 0.09139 & & 2.0060 & 1.6309 & 1.2855 & 0.9727 & 0.6989 & 0.4685 & 0.2854 & 0.1516 \\
\hline & 0.1991 & & 3.5884 & 2.8976 & 2.2640 & 1.6957 & 1.2022 & 0.7932 & 0.4729 & 0.2446 \\
\hline & 0.3869 & & - & - & - & 2.3008 & 1.5992 & 1.0278 & 0.5931 & 0.2939 \\
\hline & 0.5106 & & 5.7924 & 4.5772 & 3.4862 & 2.5301 & 1.7257 & 1.0843 & 0.6078 & 0.2905 \\
\hline & 0.9762 & & 6.2551 & 4.7818 & 3.4957 & 2.4153 & 1.5503 & 0.9023 & 0.4607 & 0.1460 \\
\hline & 1.4834 & & 5.5277 & 4.0718 & 2.8457 & 1.8621 & $-1)$ & - & & - \\
\hline
\end{tabular}

1) Solubility limit surpassed. 
Table 2

Conductance parameters, Equation (1), and their standard deviations

\begin{tabular}{|c|c|c|c|c|c|c|c|c|c|c|}
\hline \multirow{2}{*}{ Electolyte } & \multirow{2}{*}{$\frac{\theta}{{ }^{\circ} \mathrm{C}}$} & \multirow{2}{*}{$\frac{\sigma_{\text {fit }} 10^{5}}{\Omega^{-1} \mathrm{an}^{-1}}$} & \multirow{2}{*}{$\frac{\kappa_{\max }: O^{3}}{\Omega^{-1} \mathrm{~cm}^{-1}}$} & \multirow{2}{*}{$\frac{\sigma\left(\kappa_{\max }\right) 10^{5}}{\Omega^{-1} a m^{-1}}$} & \multirow{2}{*}{$\frac{\mu}{\mathrm{mol} / \mathrm{kg} \text { solv. }}$} & \multirow{2}{*}{$\frac{\sigma(\mu) 10^{2}}{\mathrm{~mol} / \mathrm{kg} \mathrm{solv}}$} & \multirow{2}{*}{$a$} & \multirow{2}{*}{$\sigma(a)$} & \multirow{2}{*}{$-\frac{10 \mathrm{~b}}{(\mathrm{~mol} / \mathrm{kg} \mathrm{solv})^{-2}}$} & \multirow{2}{*}{$\frac{10 \sigma(b)}{(\mathrm{mol} / \mathrm{kg} \mathrm{solv})^{-2}}$} \\
\hline & & & & & & & & & & \\
\hline \multirow[t]{8}{*}{$\mathrm{LiCl}_{4}$} & 25 & 1.9 & 5.420 & 1.2 & 0.6616 & 0.75 & 0.855 & 0.063 & 0.8 & 0.7 \\
\hline & 15 & 1.6 & 4.279 & 1.0 & 0.6237 & 0.67 & 0.858 & 0.065 & 1.1 & 0.8 \\
\hline & 5 & 1.3 & 3.253 & 1.0 & 0.5832 & 0.65 & 0.862 & 0.074 & 1.5 & 0.9 \\
\hline & -5 & 1.0 & 2.357 & 0.8 & 0.5398 & 0.54 & 0.868 & 0.077 & 1.9 & 0.9 \\
\hline & -15 & 0.7 & 1.604 & 0.7 & 0.4947 & 0.46 & 0.879 & 0.091 & 2.5 & 1.1 \\
\hline & -25 & 0.5 & 1.0084 & 0.51 & 0.4447 & 0.32 & 0.875 & 0.095 & 3.3 & 1.2 \\
\hline & -35 & 0.2 & 0.5681 & 0.29 & 0.3938 & 0.30 & 0.893 & 0.10 & 4.2 & 1.3 \\
\hline & -45 & 0.1 & 0.2747 & 0.13 & 0.3410 & 0.46 & 0.909 & 0.11 & 5.3 & 1.6 \\
\hline \multirow[t]{8}{*}{ LiPF, } & 25 & 2.3 & 5.409 & 2.0 & 0.857 & 2.9 & 1.093 & 0.059 & -0.4 & 1.5 \\
\hline & 15 & 1.9 & 4.182 & 1.7 & 0.800 & 1.8 & 1.088 & 0.060 & -0.1 & 1.6 \\
\hline & 5 & 1.5 & 3.111 & 1.4 & 0.744 & 1.1 & 1.090 & 0.063 & -0.1 & 1.7 \\
\hline & -5 & 1.1 & 2.205 & 1.1 & 0.686 & 0.70 & 1.094 & 0.061 & 0.3 & 1.6 \\
\hline & -15 & 0.8 & 1.469 & 0.8 & 0.625 & 0.67 & 1.089 & 0.067 & 1.0 & 1.8 \\
\hline & -25 & 0.5 & 0.9028 & 0.4 & 0.563 & 0.68 & 1.093 & 0.064 & 1.3 & 1.8 \\
\hline & -35 & 0.3 & 0.4970 & 0.3 & 0.500 & 0.74 & 1.094 & 0.071 & 1.9 & 2.0 \\
\hline & -45 & 0.5 & 0.2344 & 0.4 & 0.426 & 1.9 & 1.22 & 0.45 & -0.5 & 10 \\
\hline \multirow[t]{8}{*}{$\mathrm{KPF}_{6}$} & 25 & 1.7 & 7.307 & 1.6 & 0.971 & 2.7 & 0.886 & 0.023 & -1.1 & 0.05 \\
\hline & 15 & 1.2 & 5.711 & 0.9 & 0.881 & 1.2 & 0.887 & 0.020 & -0.9 & 0.5 \\
\hline & 5 & 0.5 & 4.294 & 0.4 & 0.799 & 0.4 & 0.900 & 0.011 & -1.0 & 0.3 \\
\hline & -5 & 0.8 & 3.092 & 0.6 & 0.725 & 0.4 & 0.889 & 0.021 & -0.3 & 0.5 \\
\hline & -15 & 0.6 & 2.089 & 0.4 & 0.655 & 0.4 & 0.891 & 0.022 & -0.02 & 0.5 \\
\hline & -25 & 0.4 & 1.301 & 0.3 & 0.582 & 0.4 & 0.895 & 0.025 & 0.3 & 0.6 \\
\hline & -35 & 0.2 & 0.7258 & 0.16 & 0.509 & 0.4 & 0.896 & 0.024 & 0.8 & 0.6 \\
\hline & -45 & 0.15 & 0.3468 & 0.11 & 0.436 & 0.4 & 0.893 & 0.033 & 1.6 & 0.9 \\
\hline \multirow[t]{8}{*}{$\mathrm{KSCN}$} & 25 & 0.8 & 7.003 & 0.6 & 1.0968 & 0.54 & 0.754 & 0.012 & -0.9 & 0.1 \\
\hline & 15 & 0.7 & 5.417 & 0.5 & 0.9756 & 0.36 & 0.754 & 0.012 & -0.9 & 0.1 \\
\hline & 5 & 0.3 & 4.043 & 0.18 & 0.8671 & 0.20 & 0.753 & 0.007 & -0.8 & 0.1 \\
\hline & -5 & 0.1 & 2.885 & 0.07 & 0.7670 & 0.10 & 0.756 & 0.004 & -0.7 & 0.04 \\
\hline & -15 & 0.1 & 1.943 & 0.07 & 0.6743 & 0.13 & 0.755 & 0.006 & -0.6 & 0.1 \\
\hline & -25 & 0.1 & 1.216 & 0.09 & 0.5861 & 0.16 & 0.756 & 0.009 & -0.3 & 0.1 \\
\hline & -35 & 0.1 & 0.6851 & 0.09 & 0.5048 & 0.18 & 0.744 & 0.015 & 0.2 & 0.2 \\
\hline & -45 & 0.04 & 0.3348 & 0.03 & 0.4261 & 0.08 & 0.732 & 0.011 & 0.9 & 0.2 \\
\hline $\mathrm{Et}_{4} \mathrm{~N}^{\prime} \mathrm{F}_{6}$ & 25 & 0.4 & 12.23 & $5.1 * *)$ & 1.795 & 8.7 & 0.907 & 0.008 & -0.8 & 0.1 \\
\hline & 15 & 0.4 & 9.500 & $2.3 *)$ & 1.590 & 4.2 & 0.908 & 0.008 & -0.8 & 0.1 \\
\hline & 5 & 0.3 & 7.125 & $0.8 * 1$ & 1.423 & 2.0 & 0.911 & 0.008 & -0.8 & 0.1 \\
\hline & -5 & 0.2 & 5.102 & $0.3 * 1$ & 1.272 & 1.2 & 0.913 & 0.009 & -0.8 & 0.1 \\
\hline & -15 & 0.3 & 3.477 & 0.2 & 1.131 & 0.7 & 0.897 & 0.013 & -0.7 & 0.2 \\
\hline & -25 & 0.1 & 2.150 & 0.1 & 0.997 & 0.3 & 0.917 & 0.011 & -0.8 & 0.1 \\
\hline & -35 & 0.03 & 1.208 & 0.03 & 0.885 & 0.3 & 0.926 & 0.008 & -1.1 & 0.1 \\
\hline & -45 & 0.2 & 0.5811 & 0.1 & 0.759 & 1.2 & 1.003 & 0.093 & -2.6 & 1.7 \\
\hline $\mathrm{Pr}_{4} \mathrm{~N}^{\prime} \mathrm{F}_{6}$ & 25 & 2.8 & 8.468 & $* *)$ & 1.17 & 19 & 0.919 & 0.047 & -1.2 & 1.1 \\
\hline & 15 & 2.2 & 6.525 & $5.7 * * 1$ & 1.06 & 10 & 0.918 & 0.046 & -1.2 & 1.1 \\
\hline & 5 & 1.7 & 4.846 & $2.2 * 1$ & 0.956 & 5.6 & 0.919 & 0.047 & -1.2 & 1.1 \\
\hline & -5 & 1.3 & 3.436 & 1.0 & 0.860 & 3.0 & 0.928 & 0.050 & -1.3 & 1.2 \\
\hline & -15 & 0.8 & 2.284 & 0.9 & 0.720 & 2.7 & 0.852 & 0.078 & 1.5 & 2.6 \\
\hline & -25 & 0.5 & 1.4166 & 0.5 & 0.654 & 1.4 & 0.861 & 0.075 & 1.4 & 2.5 \\
\hline & -35 & 0.3 & 0.7877 & 0.3 & 0.580 & 0.6 & 0.876 & 0.071 & 1.2 & 2.4 \\
\hline & -45 & 0.2 & 0.3768 & 0.1 & 0.503 & 0.6 & 0.880 & 0.076 & 1.2 & 2.6 \\
\hline $\mathrm{Bu}_{4} \mathrm{NP}_{6}$ & 25 & 1.8 & 6.305 & 1.6 & 0.840 & 0.7 & 0.909 & 0.016 & -1.2 & 0.2 \\
\hline & 15 & 1.5 & 4.878 & 1.3 & 0.778 & 0.6 & 0.910 & 0.016 & -1.2 & 0.2 \\
\hline & 5 & 1.0 & 3.639 & 0.9 & 0.715 & 0.5 & 0.913 & 0.015 & -1.2 & 0.2 \\
\hline & -5 & 2.6 & 2.582 & 2.0 & 0.666 & 1.5 & 0.883 & 0.045 & -0.7 & 0.7 \\
\hline & -15 & 2.2 & 1.734 & 2.6 & 0.601 & 2.2 & 0.893 & 0.11 & -0.9 & 0.3 \\
\hline & -25 & 1.1 & 1.080 & 1.1 & 0.536 & 1.9 & 0.907 & 0.087 & -1.1 & 0.3 \\
\hline & -35 & 0.5 & 0.6068 & 0.4 & 0.475 & 1.3 & 0.917 & 0.064 & -1.3 & 0.2 \\
\hline & -45 & 0.4 & 0.2975 & 0.3 & 0.408 & 1.4 & 0.805 & 0.11 & 9.0 & 3.5 \\
\hline
\end{tabular}


Table 2 summarizes the parameters derived from the measurements in Table 1. Satisfactory accuracy is always observed in cases of sufficiently high electrolyte solubility, i. e. if measurements were possible to a concentration exceeding $\mu$. Otherwise the quality of fit ranges from good [cf. $\left({ }^{*}\right)$ in Table 2] to moderate [cf. $\left.\left({ }^{* *}\right)\right]$.

A feature of Equation (1) must be considered at this point. In spite of a good representation of data around the point $\left(\mu, \kappa_{\max }\right)$, misrepresentations can occur at very low and high concentrations. The physically necessary condition $\kappa \rightarrow 0$ if $m \rightarrow 0$ is only fulfilled if $a>0$, otherwise $\kappa \rightarrow \infty$. Table 2 shows that this situation never occurs in our measurements. The limiting tangent $(\mathrm{d} \kappa / \mathrm{d} m)_{0}$ is always erroneous. However, the resulting deviations of the fitted curves from the measured values are limited to very small con-
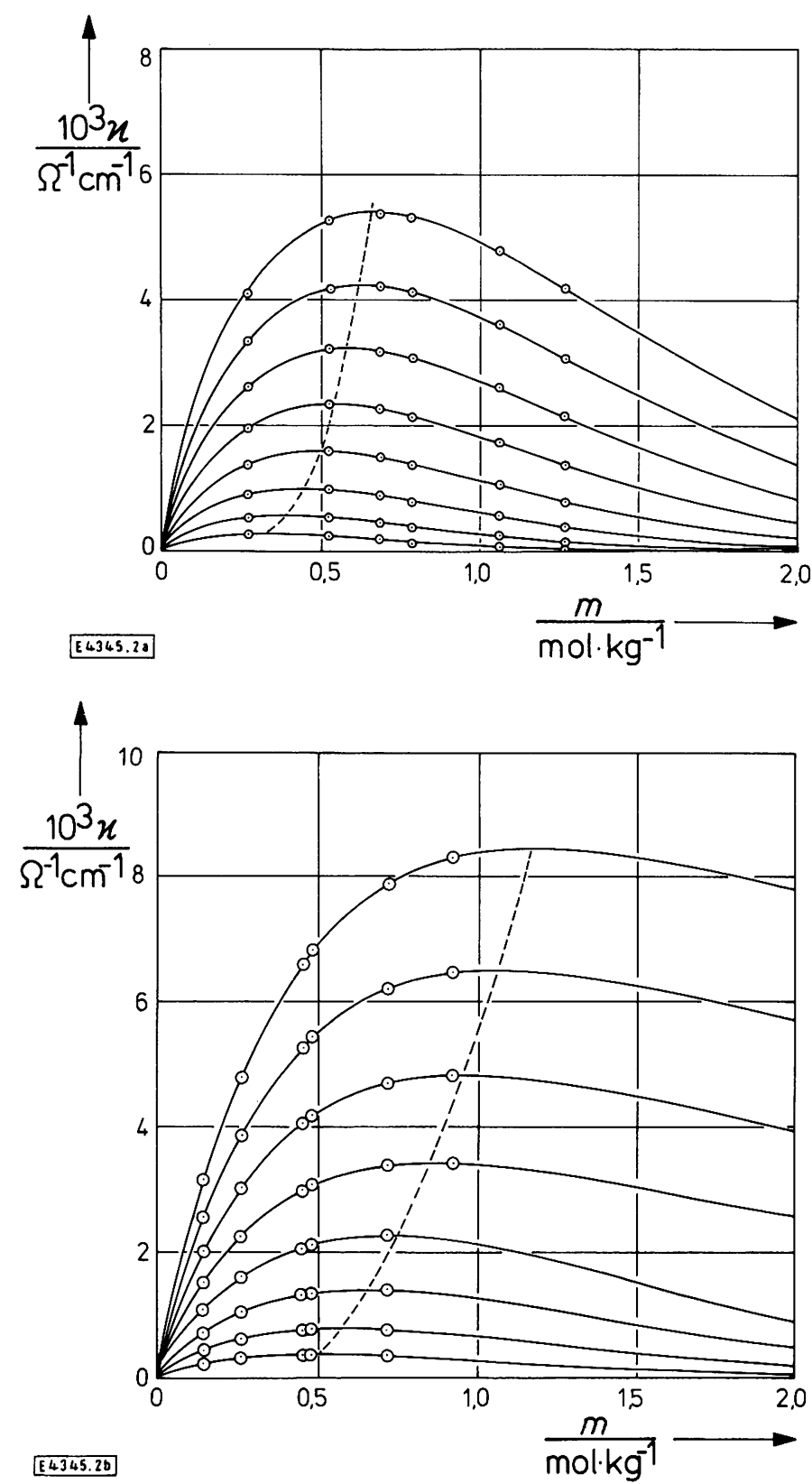

Fig. 2

Specific conductivity $10^{3} \cdot \kappa /\left(\Omega^{-1} \mathrm{~cm}^{-1}\right)$ in propylene carbonate as the solvent at temperatures from $+25^{\circ} \mathrm{C}$ to $-45^{\circ} \mathrm{C}$ in steps of $10 \mathrm{~K}$. Solid curves as obtained from computer-plots according to Equation (1). The dotted curves represent the independently determined $\kappa_{\max }=\kappa_{\max }(\mu)$ functions.
(a) $\mathrm{LiClO}_{4}$
(b) $\mathrm{Pr}_{4} \mathrm{NPF}_{6}$

centrations $\left(m<0.02 \mathrm{~mol} \mathrm{~kg}^{-1}\right)$. At high concentrations, $n \gg \mu$ finite values of $\kappa$ are obtained only if $b<0$, otherwise $\kappa$ attains a minimum at $m=\frac{a}{2 b \mu}$ and then increases steadily, in contrast to a real behaviour of $k$.

Fig. $2 \mathrm{a}, \mathrm{LiClO}_{4}$ in $\mathrm{PC}$, gives an example with $a>0, b<0$ at all temperatures of the programme. The case of $a<0$ can occur when the coefficients of Equation (1) are determined from measurements at only high concentrations, that of $b>0$ in the reverse case. The latter situation is often found when the concent:ation range is limited by the solubility of the electrolyte to concent:ation $m \approx \mu$. Nevertheless, an acceptable representation of conductance is possible by the inclusion of $\mu$-values extrapolated in a $c-m-T$ field. As an example, $\operatorname{Pr}_{4} \mathrm{NPF}_{6}$, Table 2, shows an inversion from negative to positive $b$-values at a temperature between $-15^{\circ}$ and $-5^{\circ} \mathrm{C}$ as a result of a solubility-limited concentration range [cf. Table 1 and Fig. 2b]. The shape of $\kappa=\kappa(m)$, Equation (1), at temperatures $<-5^{\circ} \mathrm{C}(b<0)$ is that observed in Fig. 2a, whereas that at temperatures $>-5^{\circ} \mathrm{C}(b>0)$ differs distinctly. In se:tions 4.4 and 4.5 the fundamental expressions governing the funtions $\mu=\mu(T), \kappa_{\max }=\kappa_{\max }(T)$, and $\kappa_{\max }=\kappa(\mu)$ are given. So the ralues $\mu$ and $\kappa_{\max }$ can be determined by an extrapolation independent of Equation (1). Figs. $2 \mathrm{a}$ and $2 \mathrm{~b}$ contain these independently ob:ained functions as dashed lines showing that investigation of the conplete $\kappa-m-T$ field yields compatible information.

It should be mentioned that Casteel and Amis in their oiginal work on Equation (1) [11] found also cases where $b>0$, e.g. $\mathrm{MgCl}_{2}$ in one of their water-ethanol mixtures. Information on aqueous systems are given in a following paper [15].

\section{Discussion}

\subsection{Maximum Specific Conductance}

The maximum of the specific conductance $\kappa_{\max }$ ard its interpretation is one of the main interests of investigations on concentrated electrolytes (e. g. $[1,4,5,11,16-20])$. The sfrecific conductance $\kappa\left[\Omega^{-1} \mathrm{~cm}^{-1}\right]$ is related to the molar conductance

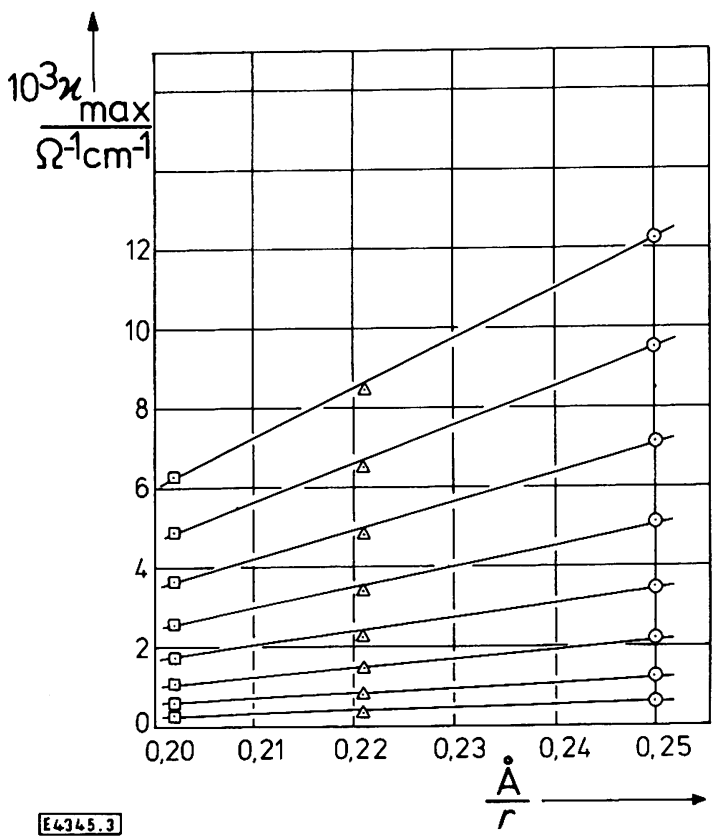

Fig. 3

Functions $10^{3} \cdot \kappa_{\max }=f\left(r_{+}^{-1}\right)$ for tetraalkylammonium hexalluorophosphates in propylene carbonate as the solvent at temperatures from $+25^{\circ} \mathrm{C}$ to $-45^{\circ} \mathrm{C}$ in steps of $10 \mathrm{~K}$

$\odot \mathrm{Et}_{4} \mathrm{NPF}_{6}, \triangle \mathrm{Pr}_{4} \mathrm{NPF}_{6}, \quad \square \mathrm{Bu}_{4} \mathrm{NPF}_{6}$ 
$\Lambda\left[\mathrm{S}^{-1} \mathrm{~cm}^{2} \mathrm{~mol}^{-1}\right]$ and the molar density function $\rho[\mathrm{mol}$ $\left.\mathrm{cm}^{-3}\right]$ of the electrolyte compound by the relationship $\kappa=\Lambda \cdot \rho$ yielding the expression

$\mathrm{d} \kappa=\Lambda \mathrm{d} \rho+\rho \mathrm{d} \Lambda$.

Exprimental evidence shows that $\mathrm{d} \Lambda<0$ if $\mathrm{d} \rho>0$ and coniequently the maximum specific conductance, when $\mathrm{d} \kappa=0$, follows from the competition between the increase $\mathrm{d} \rho$ ) f the ionic density and the lowering $\mathrm{d} \Lambda$ of the ionic motility when the electrolyte concentration increases. Molenat denes that structures change with varying concentration [18] and leaves undecided the question of which factors govern the variation of the ionic mobility. In contrast, Valyashkow and Ivanov [16] stress the competition of ion-solvent and ion-on interaction, whereas Jasinski [1] favours ion associaton as the important feature for explaining the maximum of tie specific conductance (cf. also [3]).

The comprehensiveness of the data given in Table 1 permits for he first time some insight into these problems for solutions of al aprotic solvent, propylene carbonate.

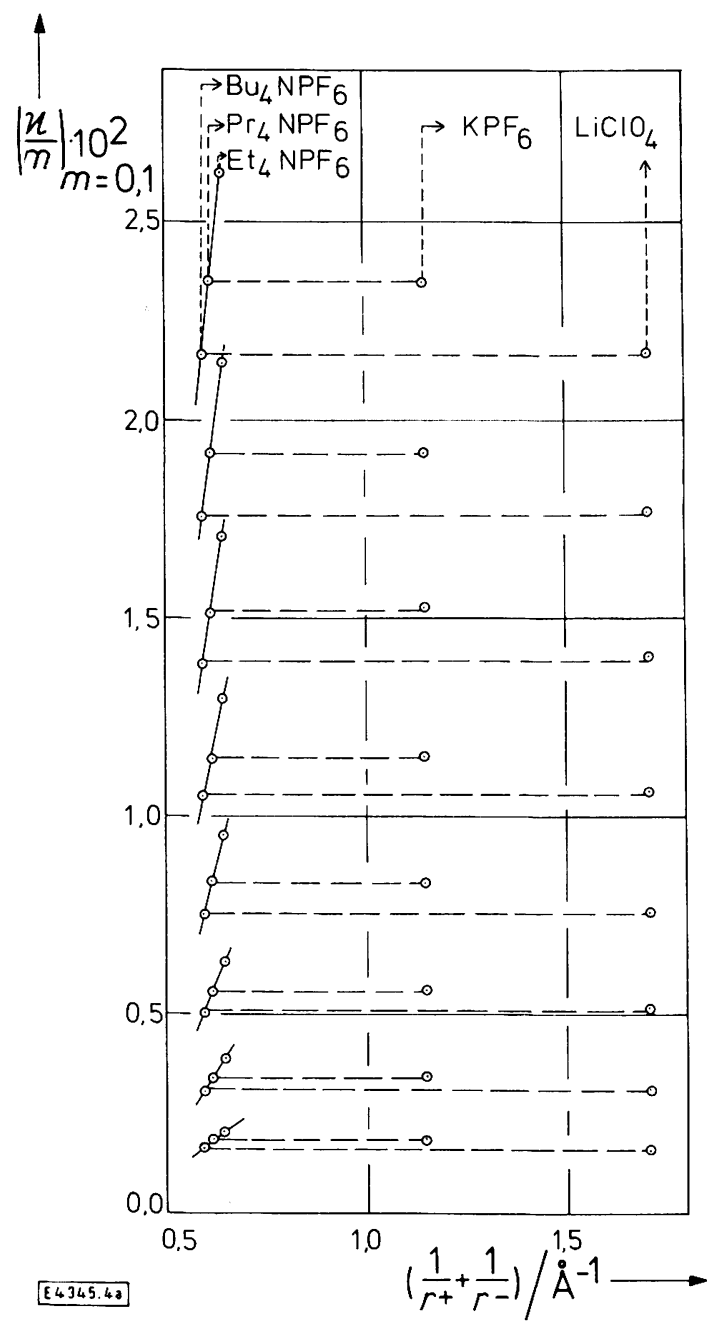

\subsection{Influence of Ionic or Stokes' Radii on Conductance}

Fig. 3 shows an approximate linear dependence of $\kappa_{\max }$ on reciprocal radii of the tetraalkylammonium ions. In addition, the ratio $\kappa_{\max }\left(\mathrm{X}_{1} \mathrm{PF}_{6}\right) / \kappa_{\text {max }}\left(\mathrm{X}_{2} \mathrm{PF}_{6}\right)$ is found to be constant irrespective of temperature, e. g. from Table $2 \kappa_{\max }\left(\mathrm{Et}_{4} \mathrm{NPF}_{6}\right) /$ $\kappa_{\text {max }}\left(\mathrm{Bu}_{4} \mathrm{NPF}_{6}\right)=1.97 \pm 0.02$. Values of $\mu$ are also found to vary approximately linear with the cationic radii, $r_{+}^{-1}$. This suggests that the data for all the investigated electrolyte solutions could be expressed in the form

$\frac{\kappa}{m}=C\left(\frac{1}{r_{-}}+\frac{1}{r_{+}}\right)$

$\kappa / m$ being an appropriate expression for investigating ionsolvent interactions in the framework of conductancedetermining effects, because this expression is correlated to the electrolyte mobility and $\lim [\kappa / m] \propto \Lambda^{\infty}$. The quantity $C$ is a function of viscosity, and further parameters which need not to be specified in this context.

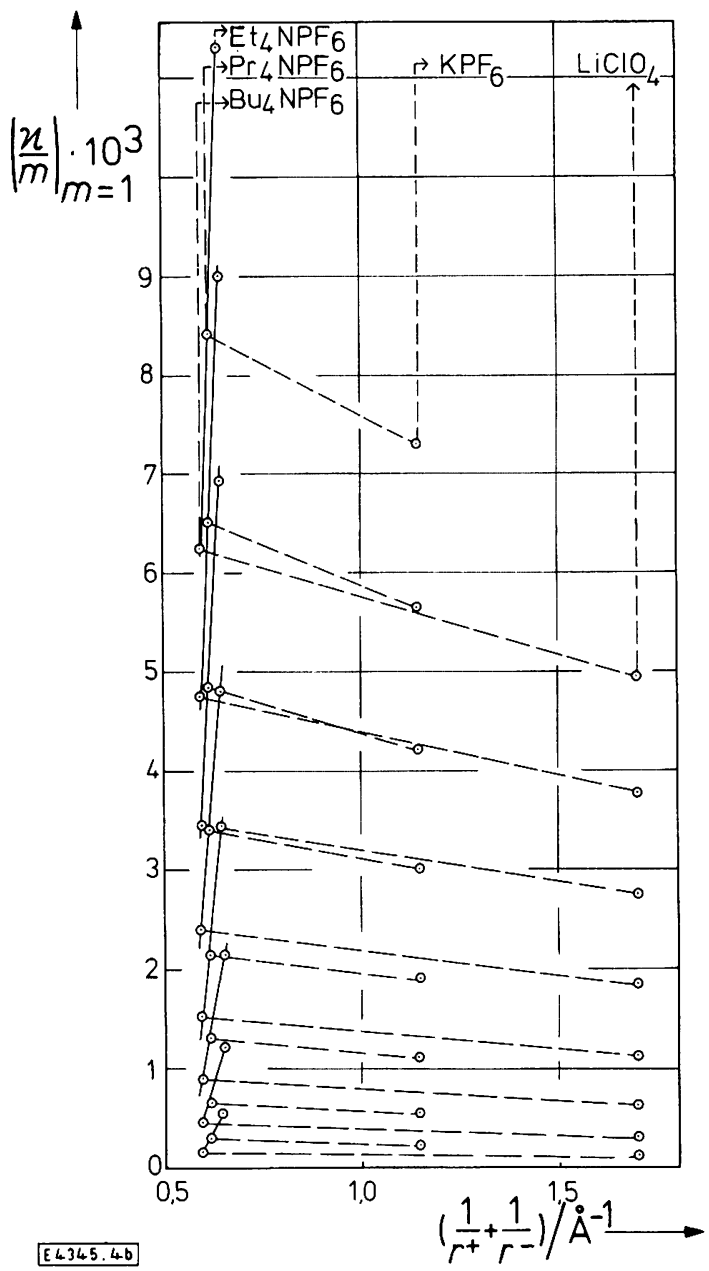

Fig. 4

Representation of $(\kappa / m)=f\left(r_{+}^{-1}+r_{-}^{-1}\right)$ for various salts in propylene carbonate at temperatures from $+25^{\circ} \mathrm{C}$ to $-45^{\circ} \mathrm{C}$ in steps of $10 \mathrm{~K}$. The dashed lines join the salts of which Stokes' radii are compared in the text.
(a) $m=0.1 \mathrm{~mol} \mathrm{~kg}^{-1}$
(b) $m=1.0 \mathrm{~mol} \mathrm{~kg}^{-1}$ 
At moderate concentrations, e.g. $m=0.1 \mathrm{~mol} \mathrm{~kg}^{-1}$ in 'Fig. 4a, Equation (3) is fulfilled by the experimental data of the three tetraalkylammonium salts, $r_{-}$and $r_{+}$being crystallographic radii of $\mathrm{ClO}_{4}^{-}[21], \mathrm{PF}_{6}^{-}[22], \mathrm{Li}^{+}[23]$, and $\mathrm{K}^{+}[24]$ or ionic radii as given by Robinson and Stokes for the tetraalkylammonium cations [25]. Just like in infinetely dilute solutions we observe $\mathrm{d}(\kappa / m) / \mathrm{d}\left(r_{+}^{-1}\right)>0$ for the tetraalkylammonium salts and $<0$ for the alkali salts. For sake of comparison $\mathrm{LiPF}_{6}$ was investigated but the impurity of this salt (from decomposition) reduced the reliability of the conductance data. Consequently discussion has to be based on $\mathrm{LiClO}_{4}$ as an example of a lithium salt with an equally hard anion and with $r_{\mathrm{ClO}_{4}-} \approx r_{\mathrm{PF}_{6}-}-[21,22]$. It should be noted that $\mathrm{KPF}_{6}$ and $\mathrm{Pr}_{4} \mathrm{NPF}_{6}$ on the one hand and $\mathrm{LiClO}_{4}$ and $\mathrm{Bu}_{4} \mathrm{NPF}_{6}$ on the other hand yield nearly equal $\mathrm{k} / \mathrm{m}$-values at every temperature. Hence, Stokes' radii $\left(R_{+}\right)$of the alkali and ionic radii $\left(r_{+}\right)$of the tetraalkylammonium salts are found to be $R_{+}\left(\mathrm{K}^{+}\right) \approx r_{+}\left(\mathrm{Pr}_{4} \mathrm{~N}^{+}\right)$and $R_{+}\left(\mathrm{Li}^{+}\right) \approx r_{+}\left(\mathrm{Bu}_{4} \mathrm{~N}^{+}\right)$in $0.1 \mathrm{M}$ solutions in agreement with infinitely dilute solutions [26]. Ion-solvent interactions are independent of temperature and as $R\left(\mathrm{Li}^{+}\right)>R\left(\mathrm{~K}^{+}\right)$are more pronounced for $\mathrm{Li}^{+}-\mathrm{PC}$ than for $\mathrm{K}^{+}-\mathrm{PC}$.

Even at still higher concentrations, e.g. $1.0 \mathrm{~mol} \mathrm{~kg}^{-1}$ in Fig. $4 \mathrm{~b}$, the values of $\kappa / m$ of tetraalkylammonium salts show the same linear dependence on ionic radii $r_{+}^{-1}$ for tetraalkylammonium salts, however the Stokes' radii $R_{+}\left(K^{+}\right)$and $R_{+}\left(\mathrm{Li}^{+}\right)$are no longer equal to the ionic radii $r_{+}\left(\mathrm{Pr}_{4} \mathrm{~N}^{+}\right)$and

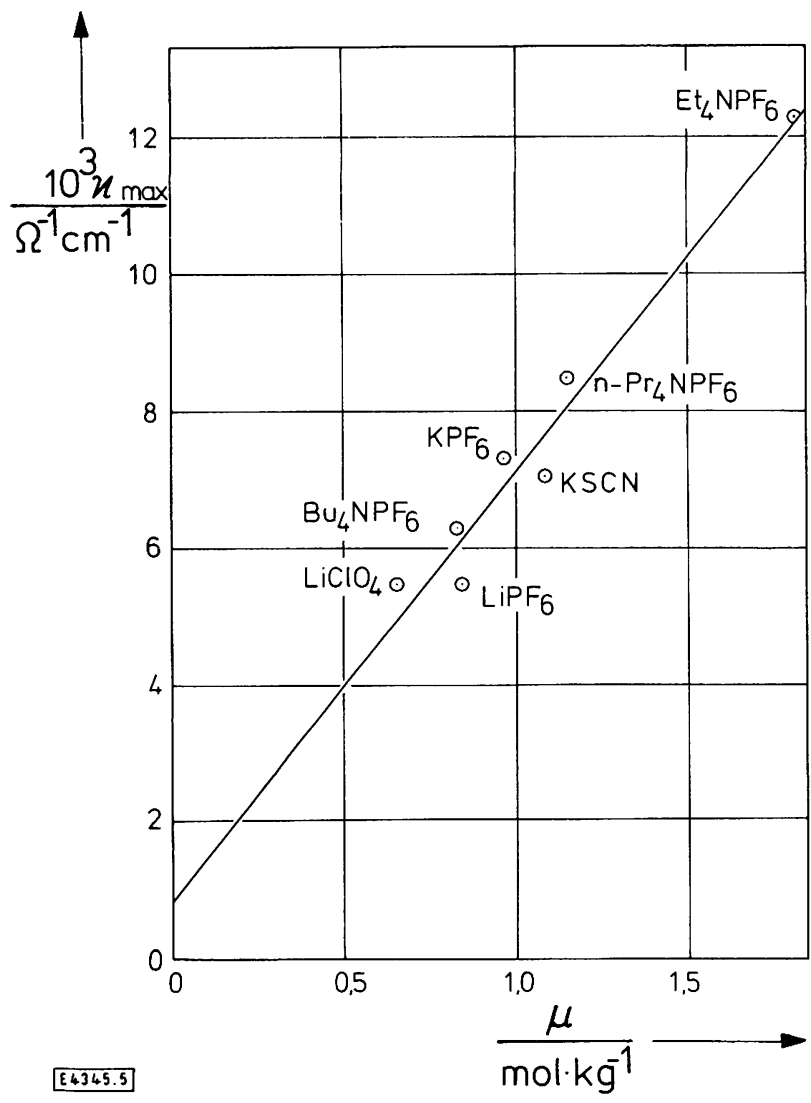

Fig. 5

Linear dependence $\kappa_{\max }=\kappa_{\max }(\mu)$ for various salts in PC at $25^{\circ} \mathrm{C}$ For further temperatures cf. Table 4
$r_{+}\left(\mathrm{Bu}_{4} \mathrm{~N}^{+}\right)$, illustrating that for the solvated alkali caions additional conductance determining effects from the itteractions in the solvation shells must have occured.

It is interesting to note that $\kappa_{\max } / \mu$ is found to be contant for all the salts investigated. Fig. 5 demonstrates this feiture with the linear representation

$\left(\kappa_{\text {max }}\right)_{25{ }^{\circ} \mathrm{C}}=(6.3 \pm 0.6) \cdot 10^{-3} \mu+(8 \pm 7) \cdot 10^{-4}$

illustrating that competition between ion-ion and ion-sovent interactions with increasing salt concentration though clanging the environment of the ions in a different way for solvated and unsolvated species leads to comparable states o the different solutions at $m=\mu$.

On the one hand, a specific hindrance such as large ionsolvent interactions, e. g. $\mathrm{Li}^{+}$, or big ionic radii, e. g. $\mathrm{Bu}_{,} \mathrm{N}^{+}$ or on the other hand a non-specific hindrance such as inceasing viscosity yield low $\mu$-values which are accompanied by low $\kappa_{\max }$-values according to Equation (4) and vice versa.

The difference in behaviour between moderately and hghly concentrated solutions can also be seen from Table 3 in a striking way. The underlying concept is a comparison of $\Lambda^{\infty}$ (for $\Lambda^{\infty}$-values of $\mathrm{LiClO}_{4}$ and $\mathrm{KPF}_{6}$ in $\mathrm{PC}$ see [30]) anl the mobility correlated function $(\kappa / m)$ by means of the quantity $A(m)=\Lambda^{\infty} /(\kappa / m)$. For both salts, $\mathrm{LiClO}_{4}$ and $\mathrm{KPF}_{6}$ the $A(0.1)$-values are independent of temperature. Hence the $(\kappa / m)$-values must depend on the temperature in the iame way as the $\Lambda^{\infty}$-values do, showing that the mobility govening effects at infinite dilution and at $m=0.1 \mathrm{~mol} \mathrm{~kg}^{-1}$ ar: the same. In contrast, a significant temperature dependene of $A(m)$ is observed at higher concentrations, e. g. $A(1.0)$. Increasing $A(m)$ values indicate decreasing mobility funcions $(\kappa / m)$. When compared at constant temperature $A(0.1)$ as well as $A(\mu)$ are almost the same for $\mathrm{LiClO}_{4}$ and $\mathrm{KPF}_{6}$ The values $A(1.0)$ differ distinctly, $A(1.0)_{\mathrm{LiClO}_{4}}>A(1.0)_{\mathrm{KP}_{6}}$ in accordance with $\mu_{\mathrm{LiClO}_{4}}<\mu_{\mathrm{KPF}_{6}}$. As previously discussel the solutions are in comparable states at $m=\mu$, conducance decreasing effects beginning to exceed the increasing efects at this characteristic concentration.

\subsection{Influence of Viscosity}

The importance of viscosity as a factor of a non-sfecific hindrance of transport is illustrated in Table 4. Pursuirg the discussion of $(\kappa / m)$ as a measure of mobility a Waldenanaloguous expression

$B=\eta_{0}\left(\kappa_{\max } / \mu\right)$

is used to show the effect of the solvent viscosity $\eta_{0}$ and its temperature dependence (for $\eta_{0}$ of $\mathrm{PC}$ at various tenperatures see [31]). The mobility function itself at $m=\mu$, $\left(\kappa_{\max } / \mu\right)$, generally varies by a factor of 10 between $+25^{\circ} \mathrm{C}$ and $-45^{\circ} \mathrm{C}$, e. g. $\mathrm{LiClO}_{4}: 8.2 \cdot 10^{-3}$ at $25^{\circ} \mathrm{C}$ and $0.81 \cdot 10^{-3}$ at $-45^{\circ} \mathrm{C}$. In contrast, the variation of $B$ is distinctly recuced, e. g. $\mathrm{LiClO}_{4}: 0.21$ at $+25^{\circ} \mathrm{C}$ and 0.27 at $-45^{\circ} \mathrm{C}$.

From the literature it is known that activation entrgies (temperature coefficients) of viscosity, $E_{\mathrm{a}}(\eta)$, and of equiralent conductance, $E_{\mathrm{a}}(\Lambda)$, or specific conductance, $E_{\mathrm{a}}(\kappa)$, are in the order $E_{\mathrm{a}}(\eta)>E_{\mathrm{a}}(\Lambda) \approx E_{\mathrm{a}}(\kappa)[16,27,28]$. The steeper decrease 
of luidity when compared to conductance as functions of temperature is in agreement with the results in Table 4. The quintity $\left(\kappa_{\max } / \mu\right)$ increases, $B$ decreases with increasing temperature.

Table 3

Valies $A(m)=m \Lambda^{\infty} / \kappa(m)$ for $\mathrm{LiClO}_{4}$ and $\mathrm{KPF}_{6}$ in propylene carbonate over a temperature range $-45 \leq \theta /{ }^{\circ} \mathrm{C} \leq+25$

\begin{tabular}{r|rrr|rrr}
\hline$\theta /{ }^{\circ} \mathrm{C}$ & \multicolumn{3}{|c|}{$\mathrm{LiClO}_{4}$} & \multicolumn{3}{c}{$\mathrm{KPF}_{6}$} \\
& $A(0.1)$ & $A(1.0)$ & $A(\mu)$ & $A(0.1)$ & $A(1.0)$ & $A(\mu)$ \\
\hline 25 & 1233 & 5418 & 3265 & 1234 & 3966 & 3848 \\
15 & 1224 & 5767 & 3163 & 1222 & 4132 & 3616 \\
5 & 1217 & 6267 & 3063 & 1205 & 4376 & 3427 \\
-5 & 1215 & 7023 & 2965 & 1202 & 4722 & 3263 \\
-15 & 1224 & 8202 & 2879 & 1198 & 5245 & 3131 \\
-25 & 1217 & 10157 & 2779 & 1198 & 6084 & 3004 \\
-35 & 1238 & 13719 & 2690 & 1202 & 7500 & 2889 \\
-45 & 1263 & 20945 & 2603 & 1216 & 10164 & 2783 \\
\hline
\end{tabular}

Table 4

Valies $B=10^{3} \eta_{0}\left(\kappa_{\max } / \mu\right)$ and $p$-values for various electrolytes in prosylene carbonate over a temperature range $-45 \leq \theta /{ }^{\circ} \mathrm{C} \leq+25$

\begin{tabular}{r|cccccc}
\hline$\theta / \mathrm{C}$ & $\mathrm{Et}_{4} \mathrm{NPF}_{6}$ & $\mathrm{Pr}_{4} \mathrm{NPF}_{6}$ & $\mathrm{Bu}_{4} \mathrm{NPF}_{6}$ & $\mathrm{LiClO}_{4}$ & $\mathrm{KPF}_{6}$ & $\mathrm{KSCN}$ \\
\hline $2 i$ & 0.172 & 0.182 & 0.190 & 0.207 & 0.190 & 0.161 \\
$1 ;$ & 0.187 & 0.192 & 0.196 & 0.214 & 0.203 & 0.173 \\
$;$ & 0.200 & 0.202 & 0.203 & 0.222 & 0.214 & 0.186 \\
$-i$ & 0.212 & 0.211 & 0.205 & 0.231 & 0.225 & 0.199 \\
$-1 ;$ & 0.225 & 0.234 & 0.213 & 0.239 & 0.235 & 0.212 \\
$-2 i$ & 0.237 & 0.238 & 0.221 & 0.249 & 0.246 & 0.228 \\
$-3 i$ & 0.245 & 0.244 & 0.230 & 0.259 & 0.256 & 0.244 \\
$-4 i$ & 0.259 & 0.254 & 0.247 & 0.273 & 0.270 & 0.266 \\
$p$ & 0.849 & 0.873 & 0.902 & 0.895 & 0.886 & 0.811 \\
\hline
\end{tabular}

$\kappa$ modified $B$-function, $B^{*}=\eta_{0}^{p}\left(\kappa_{\max } / \mu\right)$, used in analogy to : proposal of Robinson and Stokes [25] for dilute solutions, shows a range of variation which is reduced to an almost nę̣ligeable extent, e. g. $\mathrm{LiClO}_{4}(p=0.895): 0.304$ at $+25^{\circ} \mathrm{C}$, 0.316 at $-45^{\circ} \mathrm{C}$. Values of $p$ for the different salts as determined by a linear logarithmic regression are quoted in
Table 4. As in dilute electrolytes $p$ increases with the ionic radii of the tetraalkalyammonium salts.

\subsection{Temperature Dependence of $\kappa(m)$}

Smoothed values of the specific conductances $\kappa$, Equation (1), at any concentration $m$ can be calculated with the help of Table 2. From these data isologuous sections have been fitted to an expression of the form

$\ln \kappa=a+b T^{-1}+c T^{-2}$

from which activation energies, $E_{m, \theta}$, are given by $E_{m, \theta}=$ $-R(\partial \ln \kappa / \partial(1 / T))_{m, \theta}$. Table 5 gives an example.

Table 5

Activation energies $E_{\mathrm{m}, \theta} / \mathrm{kJ} \mathrm{mol}^{-1}$ of $\mathrm{KPF}_{6}$ solutions in propylene carbonate at concentrations $m / \mathrm{mol} \mathrm{kg}^{-1}$ and temperatures $\theta /{ }^{\circ} \mathrm{C}$

\begin{tabular}{r|ccccc}
\hline$\theta /{ }^{\circ} \mathrm{C}$ & 0.1 & 0.3 & 0.5 & 1.0 & 1.6 \\
\hline 25 & 12.16 & 12.36 & 12.73 & 14.13 & 16.73 \\
15 & 14.04 & 14.50 & 15.13 & 17.27 & 20.73 \\
5 & 16.05 & 16.79 & 17.17 & 20.63 & 25.20 \\
-5 & 18.20 & 19.25 & 20.48 & 24.24 & 30.01 \\
-15 & 20.55 & 21.90 & 23.46 & 28.13 & 35.20 \\
-25 & 23.09 & 24.77 & 26.69 & 32.24 & 40.78 \\
-35 & 25.80 & 27.88 & 30.18 & 36.90 & 46.84 \\
-45 & 28.77 & 31.26 & 33.98 & 41.85 & 53.54 \\
\hline
\end{tabular}

A perusal of Table 5 shows that the underlying kinetic model of electrolyte conductance provides the same information as the hydrodynamic model, section 4.2 , in so far as activation energies vary appreciably only at high concentration. $\mathrm{LiClO}_{4}$ shows this fact in an even more pronounced way (at $25^{\circ} \mathrm{C}: E_{0.1}=12.22 \mathrm{~kJ} \mathrm{~mol}^{-1} ; E_{0.3}=12.56 \mathrm{~kJ} \mathrm{~mol}^{-1}$; $E_{0.5}=12.95 \mathrm{~kJ} \mathrm{~mol}^{-1} ; E_{1.0}=14.88 \mathrm{~kJ} \mathrm{~mol}^{-1} ; E_{1.6}=$ $18.45 \mathrm{~kJ} \mathrm{~mol}^{-1}$ ) in accordance with its $\mu$-values, since $\mu_{\mathrm{LiClO}_{4}}<\mu_{\mathrm{KPF}_{6}}$. The representations of the data by equations

Table 6

Activation energies $E_{m} / \mathrm{kJ} \mathrm{mol}^{-1}$ at fixed concentrations $m / \mathrm{mol} \mathrm{kg}^{-1}$ as a function of temperature. $E_{m}(\theta)=a_{0}^{(m)}+a_{1}^{(m)} \theta+a_{2}^{(m)} \theta^{2}$

\begin{tabular}{|c|c|c|c|c|c|c|c|c|c|c|c|c|}
\hline \multirow[b]{2}{*}{ Electrolyte } & \multicolumn{4}{|c|}{$m=0.1$} & \multicolumn{4}{|c|}{$m=0.5$} & \multicolumn{4}{|c|}{$m=1.0$} \\
\hline & $a_{0}^{(m)}$ & $a_{1}^{(m)}$ & $10^{4} a_{2}^{(m)}$ & $\frac{\Delta_{\max }}{\%}$ & $a_{0}^{(m)}$ & $a_{1}^{(m)}$ & $10^{4} a_{2}^{(m)}$ & $\frac{\Delta_{\max }}{\%}$ & $a_{0}^{(m)}$ & $a_{1}^{(m)}$ & $10^{4} a_{2}^{(m)}$ & $\frac{\Delta_{\max }}{\%}$ \\
\hline $\mathrm{LiClO}_{4}$ & 17.17 & -0.2194 & 8.95 & 0.3 & 19.72 & -0.2990 & 11.54 & 0.7 & 24.48 & -0.4255 & 17.60 & 0.4 \\
\hline $\mathrm{KPF}_{6}$ & 17.08 & -0.2182 & 9.04 & 0.3 & 19.03 & -0.2790 & 11.54 & 0.3 & 22.35 & -0.3642 & 15.04 & 0.4 \\
\hline $\mathrm{KSCN}$ & 17.05 & -0.2040 & 8.42 & 0.3 & 19.21 & -0.2584 & 10.58 & 0.4 & 22.24 & -0.3317 & 13.69 & 0.4 \\
\hline $\mathrm{Et}_{4} \mathrm{NPF}_{6}$ & 16.84 & -0.2272 & 9.40 & 0.3 & 18.58 & -0.2112 & 8.75 & 0.2 & 19.78 & -0.2715 & 10.60 & 0.3 \\
\hline$n-\mathrm{Bu}_{4} \mathrm{NPF}_{6}$ & 17.41 & -0.2148 & 8.93 & 0.3 & 20.04 & -0.2508 & 10.38 & 0.3 & 22.83 & -0.4534 & 18.53 & 0.4 \\
\hline
\end{tabular}

Table 7

Activation energies $E_{\theta} / \mathrm{kJ} \mathrm{mol}^{-1}$ at fixed temperatures $\theta /{ }^{\circ} \mathrm{C}$ as a function of concentrations $E_{\theta}(m)=a_{0}^{(\theta)}+a_{1}^{(\theta)} m+a_{2}^{(\theta)} m^{2}$

\begin{tabular}{|c|c|c|c|c|c|c|c|c|c|c|c|c|}
\hline \multirow[b]{2}{*}{ Electrolyte } & \multicolumn{4}{|c|}{$\theta=15^{\circ} \mathrm{C}$} & \multicolumn{4}{|c|}{$\theta=-5^{\circ} \mathrm{C}$} & \multicolumn{4}{|c|}{$\theta=-35^{\circ} \mathrm{C}$} \\
\hline & $a_{0} \pm \sigma\left(a_{0}\right)$ & $a_{1}$ & $a_{2}$ & $\frac{\Delta_{\max }}{\%}$ & $a_{0} \pm \sigma\left(a_{0}\right)$ & $a_{1}$ & $a_{2}$ & $\frac{\Delta_{\max }}{\%}$ & $a_{0} \pm \sigma\left(a_{0}\right)$ & $a_{1}$ & $a_{2}$ & $\frac{\Delta_{\max }}{\%}$ \\
\hline$-\mathrm{iClO}_{4}$ & $13.82 \pm 0.05$ & 2.16 & 2.53 & 0.2 & $17.67 \pm 0.09$ & 5.29 & 3.66 & 0.4 & $23.7 \pm 1.0$ & 17.0 & 0.07 & 2.1 \\
\hline$\left\langle\mathrm{PF}_{6}\right.$ & $13.81 \pm 0.04$ & 1.94 & 1.50 & 0.2 & $17.71 \pm 0.10$ & 4.75 & 1.95 & 0.1 & $24.3 \pm 0.1$ & 9.4 & 1.85 & 1.0 \\
\hline KSCN & $13.82 \pm 0.05$ & 3.48 & 0.29 & 0.3 & $17.54 \pm 0.01$ & 5.58 & 0.85 & 0.1 & $24.85 \pm 0.01$ & 9.24 & 2.81 & 0.1 \\
\hline $\mathrm{it}_{4} \mathrm{NPF}_{6}$ & $13.39 \pm 0.38$ & 3.87 & -1.39 & 0.4 & $17.70 \pm 0.04$ & 3.23 & 0.21 & 0.1 & $25.5 \pm 0.5$ & 3.34 & 1.82 & 0.4 \\
\hline $3 \mathrm{u}_{4} \mathrm{NPF}_{6}$ & $13.52 \pm 0.11$ & 8.99 & -6.01 & 0.3 & $17.86 \pm 0.20$ & 6.78 & 0.40 & 0.2 & $25.8 \pm 0.4$ & 2.0 & 13.0 & 0.8 \\
\hline
\end{tabular}


Table 8

Activation energies $E_{\theta}(\mu) / \mathrm{kJ} \mathrm{mol}^{-1}$ and their mean values with mean deviations at various temperatures in solutions with propylene carbonite as the solvent

\begin{tabular}{|c|c|c|c|c|c|c|c|c|c|c|c|c|}
\hline Electrolyte & \multicolumn{2}{|c|}{$\begin{array}{l}\theta=15{ }^{\circ} \mathrm{C} \\
\mu \quad E_{\theta}(\mu)\end{array}$} & \multicolumn{2}{|c|}{$\begin{array}{c}\theta=5^{\circ} \mathrm{C} \\
\mu \quad E_{\theta}(\mu)\end{array}$} & \multicolumn{2}{|c|}{$\begin{array}{l}\theta=-5^{\circ} \mathrm{C} \\
\mu \quad E_{\theta}(\mu)\end{array}$} & \multicolumn{2}{|c|}{$\begin{array}{c}\theta=-15^{\circ} \mathrm{C} \\
\mu \quad E_{\theta}(\mu)\end{array}$} & \multicolumn{2}{|c|}{$\begin{array}{c}\theta=-25^{\circ} \mathrm{C} \\
\mu \quad E_{\theta}(\mu)\end{array}$} & \multicolumn{2}{|c|}{$\begin{array}{c}\theta=-35^{\circ} \\
\mu\end{array}$} \\
\hline $\mathrm{LiClO}_{4}$ & 0.624 & 16.2 & 0.583 & 18.9 & 0.540 & 21.6 & 0.495 & 24.5 & 0.445 & 27.1 & 0.394 & 31.0 \\
\hline $\mathrm{KPF}_{6}$ & 0.881 & 16.7 & 0.799 & 19.3 & 0.725 & 22.6 & 0.655 & 24.8 & 0.582 & 27.5 & 0.509 & 3). 3 \\
\hline $\mathrm{KSCN}$ & 0.976 & 17.5 & 0.867 & 19.9 & 0.767 & 22.3 & 0.674 & 24.7 & 0.586 & 27.1 & 0.505 & 27.6 \\
\hline $\mathrm{Et}_{4} \mathrm{NPF}_{6}$ & 1.590 & 16.1 & 1.423 & 19.5 & 1.272 & 22.2 & 1.131 & 24.7 & 0.997 & 27.2 & 0.885 & 21.9 \\
\hline $\mathrm{Bu}_{4} \mathrm{NPF}_{6}$ & 0.778 & 16.9 & 0.715 & 19.8 & 0.666 & 22.6 & 0.601 & 25.0 & 0.536 & 27.4 & 0.475 & 21.7 \\
\hline$E_{\theta}(\mu)$ & - & 16.7 & - & 19.5 & - & 22.3 & - & 24.7 & - & 27.3 & - & 2.9 \\
\hline$\Delta E_{\theta}(\mu)$ & - & 0.4 & - & 0.3 & - & 0.3 & - & 0.1 & - & 0.2 & - & 3.2 \\
\hline
\end{tabular}

Table 9

Parameters, Equation (7), their standard and maximum deviations

\begin{tabular}{|c|c|c|c|c|c|c|c|c|}
\hline Electrolytes & $\alpha$ & $\sigma(\alpha)$ & $10^{3} \beta$ & $10^{3} \sigma(\beta)$ & $10^{5} \gamma$ & $10^{5} \sigma(\gamma)$ & $10^{3} \sigma_{\mathrm{fit}}$ & $\frac{\Delta_{\max }}{\%}$ \\
\hline $\begin{array}{l}\mathrm{LiClO}_{4} \\
\mathrm{KPF}_{6} \\
\mathrm{KSCN} \\
\mathrm{Et}_{4} \mathrm{NPF}_{6} \\
\mathrm{Pr}_{4} \mathrm{NPF}_{6} \\
\mathrm{Bu}_{4} \mathrm{NPF}_{6}\end{array}$ & $\begin{array}{l}0.5618 \\
0.7651 \\
0.8160 \\
1.349 \\
0.8936 \\
0.6913\end{array}$ & $\begin{array}{l}0.0003 \\
0.0023 \\
0.0012 \\
0.005 \\
0.0007 \\
0.0002\end{array}$ & $\begin{array}{c}4.326 \\
7.76 \\
10.17 \\
15.80 \\
10.41 \\
5.99\end{array}$ & $\begin{array}{l}0.012 \\
0.10 \\
0.05 \\
0.02 \\
0.33 \\
0.09\end{array}$ & $\begin{array}{c}-1.312 \\
1.17 \\
4.07 \\
6.4 \\
3.7 \\
-0.65\end{array}$ & $\begin{array}{l}0.043 \\
0.35 \\
0.31 \\
0.8 \\
1.2 \\
0.30\end{array}$ & $\begin{array}{r}0.6 \\
4.5 \\
1.9 \\
9.9 \\
15.1 \\
4.0\end{array}$ & $\begin{array}{l}<0.2 \\
<0.7 \\
<0.3 \\
<1.2 \\
<4 \\
<0.8\end{array}$ \\
\hline
\end{tabular}

of type (6) are satisfactory, the percent deviations always being $<0.5 \%$.

From tables of type 5 for all salts, with exception of LiPF $_{6}$ (see: purity), functions $E_{m}=f(\theta)$ and $E_{\theta}=f(m)$ have been established with the help of quadratic least-squares fits for the whole temperature and concentration field. Examples are given in Tables 6 and 7.

Finally, activation energies at $m=\mu$, Table 8 , have been calculated with the help of $E_{\theta}=f(m)$.

In dilute solutions, cf. $E_{\theta}(m)$ in Table 7 when $m \rightarrow 0$, activation energies depend only on the properties of the solvent. This important feature has also been shown meanwhile by direct measurements of the conductance of highly dilute solutions with propylene carbonate [30] and further aprotic and protic solvents $[29,30]$. In contrast to acetonitrile or aliphatic alcohols where the activation energies are found to be independent of temperature, $E_{\theta}(0)$-values of solutions with $\mathrm{PC}$ as the solvent are strongly temperature-dependent. This observation is in agreement with the anomalous dependence on temperature of the viscosity of cyclic esters [32].

At high concentrations, cf. Table 6 , a sequence of activation energies $\mathrm{LiClO}_{4}>\mathrm{Bu}_{4} \mathrm{NPF}_{6}>\mathrm{KPF}_{6} \approx \mathrm{KSCN}>$ $\mathrm{Et}_{4} \mathrm{NPF}_{6}$ is observed which corresponds to the sequence of Fig. 5 based on the hydrodynamic model. At $m=1.0 \mathrm{~mol}$ $\mathrm{kg}^{-1}$, the maximum specific conductance of $\mathrm{Et}_{4} \mathrm{NPF}_{6}$ has not yet been attained whereas $\mu$ has been passed for $\mathrm{KSCN}$ and still further for $\mathrm{LiClO}_{4}$. The variation of activation energy $\mathrm{d} E_{\mathrm{a}} / \mathrm{d} m$ is a measure of variation of the ionic mobilities.

At concentration $m=\mu$ all salts in propylene carbonate yield identical activation energies at every temperature (cf. Table 8). As a rule, the maximum specific conductance for an electrolyte solution is obtained when the conductance determining effects have established a critical energy barrier which depends almost exclusively on solvent and temperature.

\subsection{Temperature Dependence of $\mu$}

The fact that interaction forces are the common bass for the quantities $\kappa_{\max }$ and $\mu$, the linear relationship between hem, Equation (4), and the temperature dependence of $\kappa_{\text {ma: }}$ discussed in 4.4 suggests a functional dependence $\mu=u(T)$. This can be empirically represented by a polynominal ieries expansion

$\mu=\alpha+\beta \theta+\gamma \theta^{2}$

with $\theta$ as the temperature in the Celsius scale.

The coefficients $\alpha, \beta$, and $\gamma$ of Equation (7) were deternined by a least-squares fit and are summarized in Table 9 togther with their standard deviations $\sigma_{\alpha}, \sigma_{\beta}$, and $\sigma_{\gamma}$ and the stardard deviation $\sigma_{\mathrm{fit}}$ of this fit. In addition, the maximum devition of the experimental quantity from the calculated one, $\Delta_{\max } \mu[\%]$, can be found. As $\mu$ is the coordinate of a nore or less flat maximum or is even sometimes found fron an extrapolation the values $\mu$ have relatively large limis of error.

It is interesting to remark that Casteel et al. [33] conclude from their measurements at $-50^{\circ} \mathrm{C}$ that the maximum of specific conductance for $\mathrm{Bu}_{4} \mathrm{NBr}$ in PC should be situated at value $\mu \approx 0.34 \mathrm{~mol}$ $\mathrm{kg}^{-1}$. From our values $\mu=\mu(\theta)$, Table 9 , a value $\mu=0.37 \mathrm{molkg}^{-1}$ can be extrapolated for $\mathrm{Bu}_{4} \mathrm{NPF}_{6}$, showing as a further exımple that anions affect the position of $\mu$ only to a small extent.

\section{References}

[1] R. Jasinski, in: Ch. W. Tobias (Ed.), Advances in El:ctrochemistry and Electrochemical Engineering, Vol. 8, Viley, New York 1971.

[2] R. Jasinski, High Energy Batteries, Plenum Press, New York 1967.

[3] J. Barthel, R. Wachter, and H. J. Gores, in: B. E. Conway and J. O'M. Bockris (Eds.), Modern Aspects of Electrochenistry, Vol. 13, Plenum Press, New York 1979. 
[4] k. I. Tikhonov, V. A. Ivanova, and B. A. Ravdel', Zh. Prikl. khim. 50, 49 (1977).

[5] F. K. Makarenko, É. A. Mendzheritskii, R. B. Sobolev, Yu. M. Fovarov, and P. A. Sereda, Elektrokhimiya 10, 355 (1974).

[6] F. Jasinski and S. Kirkland, Anal. Chem. 39, 1663 (1967).

[7] F. M. Fuoss and E. Hirsch, J. Am. Chem. Soc. 82, 1013 (1960).

[8] N. Salomon, J. Phys. Chem. 73, 3299 (1969).

[9] T. Fujinaga and K. Izutsu, Pure Appl. Chem. 27, 273 (1971).

[10] (. Jones and B. C. Bradshaw, J. Am. Chem. Soc. 55, 1780 (933).

[11] J F. Casteel and E. S. Amis, J. Chem. Eng. Data 17, 55 (1972)

[12] L. F. DeTar, Computer Programs for Chemistry, Vol. 4, fcademic Press, New York 1972.

[13] f. S. Househoulder, J. Assoc. Comput. Mach. 5, 339 (1958).

[14] E. Schollmeyer and W. Seidel, Z. Phys. Chem. (Leipzig) 257 , 1103 (1976)

[15] N. C. Vaidya, H. J. Gores, and J. Barthel (in preparation)

[16] \. M. Valyashko and A. A. Ivanov, Zh. Neorg. Khim. 19, $278(1974)$

[17] M. A. Klochko, Dokl. Akad. Nauk SSSR 82, 261 (1952)

[18] J Molenat, J. Chim. Phys. 66, 825 (1969).

[19] N. D. Surova and S. I. Zhdanov, Elektrokhimiya 9, 350 (1973).
[20] A. Than and E. S. Amis, J. Inorg. Nucl. Chem. 3I, 1685 (1969)

[21] A. F. Kapustinskii, Quart. Rev. 10, 283 (1956).

[22] H. Seifert, Fortschr. Mineral. 15, 71 (1931).

[23] V. M. Goldschmitt, Ber. Dtsch. Chem. Ges. 60, 1263 (1927)

[24] L. Pauling, Natur der Chemischen Bindung, Weinheim 1964

[25] R. A. Robinson and R. H. Stokes, Electrolyte Solutions, Academic Press, New York 1959.

[26] M. L. Jansen and H. L. Yeager, J. Phys. Chem. 77, 3089 (1973)

[27] N. M. Baron and M. U. Shcherba, Zh. Prikl. Khim. 47, 1855 (1974).

[28] T. V. Rebagy, J. F. Casteel, and P. G. Sears, J. Electrochem. Soc. 121,977 (1974)

[29] J. Barthel, F. Feuerlein, R. Neueder, and F. Straßer, J. Solution Chem. (submitted)

[30] J. Barthel, H. J. Gores, and B. Kaukal (in preparation)

[31] J. Barthel, H. J. Gores, and R. Wachter (in preparation)

[32] L. A. Girifalco, J. Chem. Phys. 23, 2446 (1955)

[33] J. F. Casteel, J. R. Angel, H. B. McNeeley, and P. G. Sears, J. Electrochem. Soc. 122, 319 (1975).

[34] R. Wachter and J. Barthel, Ber. Bunsenges. Phys. Chem 83, 634 (1979).

(Eingegangen am 6. Juni 1979)

E 4345 